\title{
Bacterial Groups Concerned with Maturing Process in Manure Production Analyzed by a Method Based on Restriction Fragment Length Polymorphism Analysis
}

\author{
Katsuji Watanabe ${ }^{*}$, Naoto Horinishi' ${ }^{1}$, Kunimasa Matumotoํㅜ, Akihiro Tanaka², \\ Kenichi Yakushido ${ }^{3}$ \\ ${ }^{1}$ Department of Life, Environment and Materials Science, Fukuoka Institute of Technology, Fukuoka, Japan \\ ${ }^{2}$ National Agricultural Research Center for Kyushu-Okinawa Region, National Agriculture and Food Research \\ Organization, Koshi, Japan \\ ${ }^{3}$ National Agricultural Research Center, National Agriculture and Food Research Organization, Tsukuba, Japan \\ Email: *k-watanabe@fit.ac.jp
}

Received 5 November 2015; accepted 7 December 2015; published 10 December 2015

Copyright (C) 2015 by authors and Scientific Research Publishing Inc.

This work is licensed under the Creative Commons Attribution International License (CC BY).

http://creativecommons.org/licenses/by/4.0/

(c) (i) Open Access

\section{Abstract}

Composting is a biological aerobic decomposition process consisted from different phases. Although the Japanese Standards for manure recommended that it took at least 6 months to complete the maturing phase, there was no reliable ground. In order to find out shortening method of the maturing phase, the microorganisms concerned with a progress of the maturing was determined by using the most probable number method (MPN) and PCR-RFLP of the 16S rDNA, which was found effective to provide numbers and taxonomy of polymyxin $B$ resistant bacterial groups in the former paper [1]. Compared to the numbers after thermophilic phase, those of Actinobacteria, $\delta$-proteobacteria, and the other gram negative bacteria increased to 50 times, 20 times, and $10^{5}$ times, respectively, after maturing phase, while those of Bacillus spp., and $\alpha$ and $\beta$-proteobacteria decreased to $1 / 10$, and $1 / 10^{5}$ after maturing phase. Numbers of the other Fumicutes, and $\gamma$ proteobacteria remained in the same revel. Actinobacteria, $\delta$-proteobacteria, and the other gram negative bacteria might be concerned with a progress of the maturing phase, because these bacterial groups were detected and enumerated due to their proliferation ability. Although number of Acitinobacteria might be underestimated because of a PCR bias, the method was found effective for the purpose to monitor bacteria actively proliferated in culture medium.

"Corresponding author.

How to cite this paper: Watanabe, K., Horinishi, N., Matumoto, K., Tanaka, A. and Yakushido, K. (2015) Bacterial Groups Concerned with Maturing Process in Manure Production Analyzed by a Method Based on Restriction Fragment Length Polymorphism Analysis. Advances in Microbiology, 5, 832-841. http://dx.doi.org/10.4236/aim.2015.513088 


\title{
Keywords
}

\author{
Maturing Phase, Manure Production, Microchip Electrophoresis, Multiple Enzyme Restriction \\ Fragment Length Polymorphism Analysis, The Most Probable Number Method
}

\section{Introduction}

Composting is not only one of the most useful ways to reduce organic wastes, such as livestock feces or sewage sludge, but also to supply organic fertilizer. As composting is a biological aerobic decomposition process consisted from different phases, microbial groups concerned with this process have intensively been investigated by using a variety of culture-based [2]-[5] and unculture-based techniques [6]-[14]. Because application of organic fertilizer, prepared under suitable composting process, has found to maintain soil fertility by amending physical, chemical and biological properties of field soil. Although the Japanese Standards for manure recommended that it took at least 6 months to complete the maturing phase, there was no reliable ground. This study was started to determine the microorganisms concerned with a progress of the maturing in order to find out shortening method of the maturing phase.

Although traditional culture based approach such as dilution plate count can clarify change of microbial population during the process, culture-based isolate is not a guarantee of the numerically dominant microorganism and its contribution remains unclear [2]-[5]. Although unculture-based technique, such as denaturing gradient gel electrophoresis (DGGE) [7] [8] [10] [11] [13] or clone library sequencing [6] [9] [11] [12] [14], targets the both cultured and uncultured microorganisms, the method only reveals variations of relative abundance of each microbial groups and a change of the microbial numbers remains unclear.

Microbial groups are not only largely changed successively in turn of the phases, but also changed by kinds of the used organic waste and manure facility, which make it difficult to determine numerically dominant microorganism in the process because of poor experimental reproducibility [6]. If the both microbial groups and their number can be clarified by a simple single experiment, a numerical change of each microbial groups by a turn of the phase will be determined more easily, which will contribute to establish suitable composting process.

Combined use of the most probable number method and PCR-RFLP of the 16S rDNA was found effective to provide numbers and taxonomies of polymyxin B resistant bacterial groups in the former paper [1]. In this manuscript, changes of numerically dominant microorganisms by a turn of the phase of manure composting were determined using this method.

\section{Materials and Methods}

\subsection{Samples of Manure}

Thermophilic process was proceeded in a full scale experimental composting tank equipped with forced aeration system settled in National Agricultural Research Center for Kyushu-Okinawa Region. In the tank, appropriate amount of rice straw and cattle feces were mixed according to an initial carbon nitrogen ratio of 20, and an initial moisture content was adjusted to about $60 \%$. During thermophilic process, the mixture was turned and mixed well one a week and temperatures at different locations in the tank were monitored to control thermophilic phase. After five weeks of thermophilic phase, the cooled manure was transformed to a composting bin covered by a shed, when the composting samples after thermophilic phase (represented as $T$ in Table 1) were collected at 5 different locations and sieved ( $<20 \mathrm{~mm}$ mesh). After 6 to 7 months of maturing phase in the bin, the composting samples after maturing (represented as $\mathrm{M}$ in Table 1) were collected at 5 different locations and sieved ( $<20 \mathrm{~mm}$ mesh). The final product was certified in compliance with the Japanese Standards for manure.

Serial 10 -fold dilutions $\left(10^{-3}\right.$ to $10^{-13}$ ) prepared from manure (1g fresh wt.) were inoculated to test vials (5 replicates) including nutrient broth. After 5 days incubation at $30^{\circ} \mathrm{C}$, bacterial DNA in each vial was extracted as the followings. Each bacterial group was counted by MPN after the phylogenetic estimations.

\subsection{MERFLP of the Amplified 16S rDNA}

Chromosomal DNAs of each MPN vials were prepared as described previously and purified by conventional 
Table 1. Affiliation of bacteria grown in serially diluted NB medium by MERFLP ${ }^{\mathrm{a}}$.

\begin{tabular}{|c|c|c|c|c|}
\hline & $\begin{array}{ll}\text { Vial } & \text { R } \\
\text { No. }^{\text {b }} & \end{array}$ & $\begin{array}{l}\text { Restriction } \\
\text { enzymes }^{c}\end{array}$ & $\begin{array}{l}\text { Similarity } \\
\text { (\%) }\end{array}$ & Name (accession number) ${ }^{d}$ \\
\hline \multirow[t]{12}{*}{ A } & $\mathrm{T} 10^{-6} 3 \mathrm{H}$ & Ha, R, Hh & 95 & \multirow{12}{*}{ B. benzovorans (D78311, X60611) } \\
\hline & $\mathrm{T} 10^{-9} 2 \mathrm{H}$ & Ha, R, Hh & 92 & \\
\hline & $\mathrm{T} 10^{-9} 3 \mathrm{H}$ & $\mathrm{Ha}, \mathrm{R}, \mathrm{Hh}$ & 100 & \\
\hline & $\mathrm{T} 10^{-9} 5 \mathrm{H}$ & Ha, R, Hh & 100 & \\
\hline & $\mathrm{T} 10^{-10} 1 \mathrm{H}$ & $\mathrm{Ha}, \mathrm{R}, \mathrm{Hh}$ & 100 & \\
\hline & $\mathrm{T} 10^{-10} 2 \mathrm{H}$ & $\mathrm{Ha}, \mathrm{R}, \mathrm{Hh}$ & 100 & \\
\hline & $\mathrm{T} 10^{-10} 5 \mathrm{H}$ & Ha, R & 100 & \\
\hline & $\mathrm{M} 10^{-8} 1 \mathrm{H}$ & Ha, R, Hh & 95 & \\
\hline & $\mathrm{M} 10^{-9} 4 \mathrm{H}$ & $\mathrm{Ha}, \mathrm{R}, \mathrm{Hh}$ & 93 & \\
\hline & $\mathrm{M} 10^{-10} 1 \mathrm{H}$ & Ha, R, Hh & 95 & \\
\hline & $\mathrm{M}^{-10}{ }^{-10} \mathrm{H}$ & $\mathrm{Ha}, \mathrm{R}, \mathrm{Hh}$ & 100 & \\
\hline & $\mathrm{M}^{-10} 5 \mathrm{H}$ & $\mathrm{HaR}, \mathrm{Hh}$ & 100 & \\
\hline \multirow[t]{9}{*}{ B } & $\mathrm{T} 10^{-6} 2 \mathrm{H}$ & Ha, R, Hh & 100 & \multirow{9}{*}{ B. sphaericus (L14011, 14012, 14014, 14015, 14016), B. licheniformis (X68416) } \\
\hline & $\mathrm{T} 10^{-6} 5 \mathrm{H}$ & Ha, R, Hh & 100 & \\
\hline & $\mathrm{T} 10^{-7} 1 \mathrm{H}$ & $\mathrm{Ha}, \mathrm{R}, \mathrm{Hh}$ & 100 & \\
\hline & $\mathrm{T} 10^{-7} 3 \mathrm{H}$ & $\mathrm{Ha}, \mathrm{R}, \mathrm{Hh}$ & 100 & \\
\hline & $\mathrm{T} 10^{-7} 5 \mathrm{H}$ & $\mathrm{Ha}, \mathrm{R}, \mathrm{Hh}$ & 100 & \\
\hline & $\mathrm{T} 10^{-8} 2 \mathrm{H}$ & Ha, R, Hh & 100 & \\
\hline & $\mathrm{T} 10^{-8} 5 \mathrm{H}$ & Ha, R, Hh & 100 & \\
\hline & $\mathrm{M} 10^{-6} 1 \mathrm{H}$ & $\mathrm{Ha}, \mathrm{R}, \mathrm{Hh}$ & 100 & \\
\hline & $\mathrm{M} 10^{-9} 3 \mathrm{H}$ & $\mathrm{HaR}, \mathrm{Hh}$ & 100 & \\
\hline \multirow[t]{14}{*}{$\mathrm{C}$} & $\mathrm{T} 10^{-6} 4 \mathrm{M}$ & Ha, R & 90 & \multirow{7}{*}{$\begin{array}{l}\text { B. thermoglucosidasius (X60641), } \\
\text { Paenibacillus macerans (Pae. macern) }\end{array}$} \\
\hline & $\mathrm{T} 10^{-10} 3 \mathrm{H}$ & $\mathrm{Ha}, \mathrm{R}, \mathrm{Hh}$ & 92 & \\
\hline & $\mathrm{T} 10^{-11} 2 \mathrm{H}$ & Ha, R, Hh & 92 & \\
\hline & $\mathrm{M} 10^{-8} 5 \mathrm{H}$ & $\mathrm{Ha}, \mathrm{R}, \mathrm{Hh}$ & 89 & \\
\hline & $\mathrm{T} 10^{-6} 1 \mathrm{H}$ & Ha, R & 100 & \\
\hline & $\mathrm{T} 10^{-7} 2 \mathrm{H}$ & $\mathrm{Ha}, \mathrm{R}, \mathrm{Hh}$ & 96 & \\
\hline & $\mathrm{M} 10^{-7} 2 \mathrm{H}$ & $\mathrm{Ha}, \mathrm{R}, \mathrm{Hh}$ & 96 & \\
\hline & $\mathrm{T} 10^{-6} 3 \mathrm{H}$ & R, Hh & 100 & \multirow{3}{*}{$\begin{array}{l}\text { B. pallidus (Z26930), B. psychrosaccharolyticus (B. psycsass), } \\
\text { B. sphaericus (B. sphaeri3), B. smithii (X60643), B. psychrosaccharolyticus (X60635), B. } \\
\text { badius (B. badius), Paenibacillus lavei (Pae. alvei3), P. lautus (Pae. lautu, Pae. lautu2) }\end{array}$} \\
\hline & $\mathrm{T} 10^{-6} 4 \mathrm{H}$ & $\mathrm{R}, \mathrm{Hh}$ & 100 & \\
\hline & $\mathrm{T} 10^{-8} 3 \mathrm{H}$ & $\mathrm{R}, \mathrm{Hh}$ & 100 & \\
\hline & $\mathrm{T} 10^{-8} 4 \mathrm{H}$ & Ha, R, Hh & 100 & $\begin{array}{l}\text { B. circulans (B. circulan, B. circula3), B. lentus (B. lentus), } \\
\text { B. maroccanus (B. maroccan), B. thermoamylovorans (B. tamyvor) }\end{array}$ \\
\hline & $\mathrm{M} 10^{-8} 2 \mathrm{H}$ & $\mathrm{Ha}, \mathrm{R}, \mathrm{Hh}$ & 89 & B. caldotenax (Z26922) \\
\hline & $\mathrm{M} 10^{-8} 4 \mathrm{H}$ & Ha, R & 100 & $\begin{array}{l}\text { B. insolitus (X60642), Clostridium tetani (C. tetani), C. cochlearium } \\
\text { (C. cochlear), C. chartatabium (C. chartata) }\end{array}$ \\
\hline & $\mathrm{M} 10^{-9} 1 \mathrm{M}$ & $\mathrm{Ha}, \mathrm{Hh}$ & 90 & B.anthracis (X55059) \\
\hline \multirow[t]{11}{*}{$\mathrm{D}$} & $\mathrm{T} 10^{-7} 2 \mathrm{M}$ & $\mathrm{R}, \mathrm{Hh}$ & 100 & Paenibacillus lautus (D85394, D85609) \\
\hline & $\mathrm{T} 10^{-8} 4 \mathrm{M}(1)^{\mathrm{e}}$ & Ha, R & 90 & Gracibacillus halotolerans (Grb. haltol) \\
\hline & $\mathrm{T} 10^{-8} 4 \mathrm{M}(2)^{\mathrm{e}}$ & $\mathrm{R}, \mathrm{Hh}$ & 90 & Haloanaerobacter chitinovorans (U32596) \\
\hline & $\mathrm{T} 10^{-11} 5 \mathrm{M}$ & Ha, R & 100 & Lactobacillus maltaromicus (M58825), Carnobacterium piscicola (X54268) \\
\hline & $\begin{array}{l}\mathrm{M} 10^{-7} 4 \mathrm{M} \\
(1)^{\mathrm{e}}\end{array}$ & $\mathrm{R}, \mathrm{Hh}$ & 90 & Spiroplasma mirum (M24662), S. citri (Spp.sit2HP), S. poulsonii (Spp. poulsn) \\
\hline & $\mathrm{M} 10^{-8} 4 \mathrm{M}$ & $\mathrm{R}, \mathrm{Hh}$ & 90 & Haloanaerobacter chitinovoran (U32596) \\
\hline & $\mathrm{M} 10^{-8} 5 \mathrm{~L}$ & $\mathrm{Ha}, \mathrm{Hh}$ & 100 & Leuconostoc gelidum (AF175402) \\
\hline & $\mathrm{M} 10^{-9} 5 \mathrm{H}$ & Ha, Hh & 100 & Desulfotomaculum putei (AF053932) \\
\hline & $\mathrm{M} 10^{-9} 5 \mathrm{M}$ & Ha, R & 100 & $\begin{array}{l}\text { Staphylococcus carnosus (AB009934), S. aureus (L37598), } \\
\text { S. condimenti (Y15750), S. piscifermenta (Y15753,Y15754) }\end{array}$ \\
\hline & $\mathrm{M} 10^{-10} 2 \mathrm{M}$ & Ha, R & 90 & Eubacterium tortuosum (Eub. tortuo) \\
\hline & $\mathrm{M} 10^{-11} 3 \mathrm{M}$ & Ha, Hh & 87 & Exiguobacterium acetylicum (D55730) \\
\hline \multirow[t]{2}{*}{$\mathrm{E}$} & $\mathrm{T} 10^{-9} 1 \mathrm{H}$ & Ha, R & 100 & Corynebacterium vitarumen (X84680) \\
\hline & $\mathrm{M} 10^{-11} 2 \mathrm{M}$ & $\mathrm{R}, \mathrm{Hh}$ & 90 & Streptomyces espinosus (Stm. espino), S. thermodiastatic (Stm. thdia2, Stm. thdia3) \\
\hline
\end{tabular}




\section{Continued}

\begin{tabular}{|c|c|c|c|c|}
\hline \multirow{3}{*}{ F } & $\mathrm{T} 10^{-9} 1 \mathrm{M}$ & Ha, Hh & 100 & Metylobacterium extorquens (Mlb. extorq) \\
\hline & $\mathrm{T} 10^{-10} 1 \mathrm{H}$ & Ha, R & 100 & Neorickettsia helminthoeca (U12457) \\
\hline & $\mathrm{T} 10^{-11} 4 \mathrm{H}$ & Ha, R & 100 & Agrobacterium vitis (U28505, U45329) \\
\hline \multirow[t]{4}{*}{ G } & $\mathrm{T} 10^{-9} 1 \mathrm{M}$ & На, R & 100 & Alcaligenes sp. (U80417) A. xylosoxydans (D88005, M22509), \\
\hline & $\mathrm{T} 10^{-11} 2 \mathrm{M}$ & $\mathrm{Ha}, \mathrm{Hh}$ & 86 & Aquaspirillum gracile (AF078753) \\
\hline & $\mathrm{T} 10^{-11} 4 \mathrm{M}$ & Ha, Hh & 90 & Niseeria gonorrhoeae (Nis. gonorr, Nisgonor1) \\
\hline & $\begin{array}{l}\mathrm{M}^{-7} 4 \mathrm{M} \\
(2)^{\mathrm{e}}\end{array}$ & Ha, Hh & 90 & Eikenella corrodens (Eik. corro2) \\
\hline \multirow[t]{8}{*}{$\mathrm{H}$} & $\begin{array}{l}\mathrm{T} 10^{-11} 3 \mathrm{H} \\
\mathrm{T} 10^{-12} 2 \mathrm{H}\end{array}$ & $\begin{array}{l}\text { Ha, R } \\
\text { Ha, R }\end{array}$ & $\begin{array}{l}100 \\
100\end{array}$ & Methylococcus capsulatus (L20842), Francisella philomiragia (Z21933) \\
\hline & $\mathrm{T} 10^{-9} 2 \mathrm{H}$ & Ha, R & 100 & Moritella japonica (Mrt. japoni), Vivrio sp. (V. sp DB510) \\
\hline & $\begin{array}{l}\mathrm{T} 10^{-10} 2 \mathrm{M} \\
\mathrm{M} 10^{-10} 1 \mathrm{M}\end{array}$ & $\begin{array}{l}\text { Ha, R } \\
\text { Ha, R }\end{array}$ & $\begin{array}{l}93 \\
93\end{array}$ & Oceanospirillum multiglobulife (АВ006763) \\
\hline & $\mathrm{T} 10^{-6} 3 \mathrm{M}$ & Ha, R & 90 & Pseudomonas chlororaphis (D84011) \\
\hline & $\mathrm{M}^{1} 0^{-7} 3 \mathrm{H}$ & $\mathrm{Ha}, \mathrm{R}, \mathrm{Hh}$ & 88 & Acinetobacter sp. (Z93441, Z93442) \\
\hline & $\mathrm{M} 10^{-8} 1 \mathrm{~L}$ & Ha, Hh & 86 & Metylobacter whttenburyi (Mbc. whtbu2) \\
\hline & $\mathrm{M} 10^{-11} 1 \mathrm{M}$ & Ha, R & 100 & Pseudomonas nitroreducens (D84022) \\
\hline & $\mathrm{M} 10^{-12} 1 \mathrm{H}$ & Ha, R & 97 & Vibrio cholerae (V. choler6,V. choler12) \\
\hline \multirow[t]{7}{*}{ I } & $\begin{array}{c}\mathrm{T} 10^{-12} 5 \mathrm{H} \\
\mathrm{M} 10^{-7} 4 \mathrm{H} \\
\mathrm{M} 10^{-9} 1 \mathrm{H} \\
\mathrm{M} 10^{-10} 5 \mathrm{Mf} \\
\mathrm{T} 10^{-7} 4 \mathrm{H} \\
\mathrm{M} 10^{-7} 1 \mathrm{H} \mathrm{f} \\
\mathrm{M} 10^{-8} 3 \mathrm{H}\end{array}$ & $\begin{array}{c}\text { Ha, R, Hh } \\
\text { Ha, R } \\
\text { Ha, R } \\
\text { Ha, Hh } \\
\text { R, Hh } \\
\text { Ha, R, Hh } \\
\text { R, Hh }\end{array}$ & $\begin{array}{c}92 \\
100 \\
100 \\
87 \\
100 \\
91 \\
100\end{array}$ & $\begin{array}{c}\text { Desulfobotulus sp. BG14 (U85470), Desulfobulbus sp. BG25 (U85473), } \\
\text { Desufonema limicola (U45990) }\end{array}$ \\
\hline & $\mathrm{T} 10^{-9} 4 \mathrm{M}$ & Ha, Hh & 90 & Desulfomonas acetoxidans (Dsm. acetox) \\
\hline & $\mathrm{M} 10^{-8} 2 \mathrm{M}$ & $\mathrm{R}, \mathrm{Hh}$ & 90 & Desufovibrio africanus (M37315) \\
\hline & $\mathrm{M} 10^{-9} 2 \mathrm{H}$ & Ha, R, Hh & 88 & $\begin{array}{c}\text { Myxococcus stipitatus (AJ233922), M. virescens (AJ233925), M. xanthus (AJ233930), } \\
\text { Archangium gephyra (AJ233913), Corallococcus exiguus (AJ233932) }\end{array}$ \\
\hline & $\mathrm{M} 10^{-11} 2 \mathrm{H}$ & Ha, R, Hh & 92 & Desulfovibrio sp. zt31 (AF109470), D. intestinalis (Y12254), \\
\hline & $\mathrm{M} 10^{-11} 3 \mathrm{H}$ & Ha, Hh & 100 & Desulfobacterium indolicus (AJ237607) \\
\hline & $\mathrm{M} 10^{-12} 1 \mathrm{H}$ & $\mathrm{R}, \mathrm{Hh}$ & 93 & Desulfomonile tiedjei (M26635) \\
\hline \multirow[t]{4}{*}{$\mathrm{J}$} & $\begin{array}{l}\mathrm{T} 10^{-7} 1 \mathrm{M} \\
\mathrm{M} 10^{-11} 1 \mathrm{H}\end{array}$ & $\begin{array}{l}\text { Ha, R } \\
\text { Ha, R, Hh }\end{array}$ & $\begin{array}{c}100 \\
89\end{array}$ & Telluria chitinolytica (X65590) \\
\hline & $\mathrm{M} 10^{-7} 3 \mathrm{H}$ & Ha, R & 93 & $\begin{array}{l}\text { Fusobacterium necrophorum (AF044948), F. russii (Fus. russi), F. mortiferum } \\
\text { (Fus. morti3), F. varium (Fus. varium), Streptobacillus moniliformis (Stb. monil2) }\end{array}$ \\
\hline & $\mathrm{M} 10^{-8} 1 \mathrm{M}$ & Ha, R & 95 & Borrelia anserina (U42284) \\
\hline & $\mathrm{M} 10^{-12} 1 \mathrm{H}$ & На, R & 93 & Leptospira fainei (U60594), L. inadai (Z21634) \\
\hline
\end{tabular}

${ }^{a}$ Grouping was based on affiliation by MERFL; B. benzovorans (Group A), B. sphaericus and, B. licheniformis (Group B), the other Bacillus spp. (Group C), the other Firmicutes (Group D), Actinobacteria (Group E), $\alpha$-proteobacteria (Group F), $\beta$-proteobacteria (Group G), $\gamma$-proteobacteria $($ Group H), $\delta$-proteobacteria (Group I), and the other gram negative bacterial group (Group J). 'The 1st letter in vial indicates samples; "T" stands for the sample after thermophilic phase, and "M" stands for the sample after maturing phase. Exponential of vial number represents the decimal dilution of the vial. The 2nd number of vial number (1 - 5) represents number in 5 replicates for the each decimal dilution. H of last letter represents MERFL originating from the major $16 \mathrm{~S}$ rDNA, M represents from the 2nd major $16 \mathrm{~S}$ rDNA, and L represents from the 3rd major 16S rDNA. 'Restriction enzymes used for similarity search; "Ha”, "Hh", and "R" stand for Hae III, Hha I, and Rsa I. For the measured MERFLP which had no completely identical theoretical MERFLP, the theoretical MERFLP having the highest similarity using all the RFLPs was presented with the similarity as described in the materials and method. ${ }^{\mathrm{d}}$ Species name (accession number) of the theoretical MERFL having the highest similarity with the measured MERFL. ${ }^{\mathrm{e}}$ Additional name (accession number) of the theoretical MERFL using the different restriction enzymes. ${ }^{\mathrm{f}}$ The same genus having the different MERFLs. 
methods. Amplification of 16S rDNA was according to the former study [15] [16] using the V2 forward primer (41f), and the V6 reverse primer (1066r) [17] [18]. PCR product (10 $\mu$ l) was separately digested by each of 10 units of the restriction enzyme, Hae III or Hha I or Rsa I (Takara Bio Co. Ltd. Shiga Japan) in Low salt buffer solution (10xLow salt buffer, Takara Bio Co. Ltd.).

\subsection{Fragment Lengths Measurement by Microchip Electrophoresis System}

Fragment lengths were measured by microchip electrophoresis system (Cosmo-i SV1200; Hitachi Electronics Engineering Co., Ltd. Tokyo Japan) as described previously [16] [19]. The sample was diluted by de-ionized water (10 folds for Low salt buffer) before loading on i-tip DNA (IC-1000, Hitachi Chemical Industry Co., Ltd., Tokyo Japan). DNA fragment (65 bp) was used as the lower internal standard, and the PCR product amplified by 41f/1066r primers was used as the upper internal standard, which were co-applied with samples as described previously [10] [11]. In the next similarity search process, the fragment smaller than 100bp was eliminated from the both theoretical and measured MERFLs as described previously [15].

\subsection{Theoretical Multiple Enzyme Restriction Fragment Lengths (MERFL) Database Used for the Estimation}

The same theoretical MERFL database as that described previously [1] [10] [11] was used for this research, which was consisted from 4370 sequence files of 576 bacterial genera, and 143 uncultured and 34 unidentified bacteria.

\subsection{Data Processing for Phylogenetic Estimation Using Multi-Template DNA and Phylogenetic Estimation}

As each MPN vials included multi-template DNAs originated from heterogeneous bacteria, most of the measured MERFLP was the mixed MERFLPs digested from the heterogeneous 16S rDNA. Whereas all the theoretical MERFLs were originated from the homogeneous 16S rDNA sequence, the measured MERFLP digested from the homogeneous 16S rDNA was selected as described previously [1].

The restriction fragments (RFs) with the highest relative mole concentration (ratio of fluorescent intensity to fragment size) were selected and used as the major RFs (represented as $\mathrm{H}$ in Table 1). After subtraction of the above the major RFs from the mixed heterogeneous RFs, RFs originated from the 2nd major gene were similarly selected and used for similarity search (represented as M in Table 1). After subtraction of the above 2nd major RFs from the remained heterogeneous RFs, RFs originated from the 3rd major gene were similarly selected and used for similarity search (represented as L in Table 1 ).

The similarity between the measured RFLP (A) and the theoretical RFLP (B) was calculated as described previously [15] [16] [20] based on the pairwise distance $\left(D_{A B}\right)$ by the following equation; $D_{A B}=1-2 N_{A B} /\left(N_{A}+N_{B}\right)$, where $N_{A}$ and $N_{B}$ were the numbers of fragments of each RFLPs and $N_{A B}$ was the number of shared fragments that indicated same sizes within an allowance limit for measuring error according to Nei and Li [21]. The pairwise distance of the MERFLPs $\left(D_{A B M E}\right)$ was an average of all the $D_{A B s}$ for used restriction enzymes. Similarity (\%) was $\left(1-D_{A B M E}\right) \times 100$ (Table 1$)$.

If the completely identical theoretical MERFL was not found out by using all of the measured MERFL data, combinations of restriction enzymes used for the analysis was changed (Table 1) [15] [16]. As to the measured MERFL which had no completely identical theoretical MERFL, the theoretical MERFL having the highest similarity to the measured MERFL was indicated in Table 1 [15] [16].

\subsection{Estimation of Numbers of Each Taxonomically Different Groups by the Most Probable Number Method}

Most probable numbers of each groups (A - J) were estimated for five-tube, three-decimal-dilution experiment (Table 2). Confidence limits shown in Table 2 were obtained using Woodward's method [22].

\section{Results and Discussion}

\subsection{Affiliation of Bacteria by MERFLP without Isolation}

Affiliations of eighty one MERFLPs in each MPN vials were summarized in Table 1 . They were affiliated to be 
Table 2. Most probable numbers of each groups (A - J) and 5\% confidence limits obtained using Woodward's method [22].

\begin{tabular}{|c|c|c|c|c|c|c|c|c|}
\hline \multirow{3}{*}{$\begin{array}{l}\text { Groups } \\
\text { B. benzovorans }\end{array}$} & \multicolumn{4}{|c|}{ After thermophilic phase } & \multicolumn{4}{|c|}{ After maturing } \\
\hline & \multirow{2}{*}{$\begin{array}{c}\text { Three } \\
\text { dilutions } \\
10^{-9} 10^{-10} 10^{-11}\end{array}$} & \multirow{2}{*}{$\begin{array}{l}\text { Score } \\
3-3-0\end{array}$} & \multirow{2}{*}{$\begin{array}{c}\text { MPN }\left(\times 10^{8}\right) \\
\mathrm{g}^{-1} \text { dry matter } \\
39.1\end{array}$} & \multirow{2}{*}{$\begin{array}{c}\text { 5\% limits } \\
\text { Low/High }\end{array}$} & \multirow{2}{*}{$\begin{array}{c}\begin{array}{c}\text { Three } \\
\text { dilutions }\end{array} \\
10^{-9} 10^{-10} 10^{-11}\end{array}$} & \multicolumn{2}{|c|}{$\begin{array}{c}\text { MPN }\left(\times 10^{8}\right) \\
\mathrm{g}^{-1} \text { dry matter }\end{array}$} & \multirow[t]{2}{*}{$\begin{array}{l}5 \% \text { limits } \\
\text { Low/High }\end{array}$} \\
\hline & & & & & & $1-3-0$ & 9.96 & \\
\hline $\begin{array}{l}\text { B. B. sphaericus/ } \\
\text { B. licheniformis }\end{array}$ & $10^{-7} 10^{-8} 10^{-9}$ & $3-2-0$ & 0.322 & $0.14 / 0.81$ & $10^{-8} 10^{-9} 10^{-10}$ & $0-1-0$ & 0.22 & $0.1 / 1.2$ \\
\hline C. The other Bacillus & $10^{-10} 10^{-11} 10^{-12}$ & $1-1-0$ & 92.0 & $23.0 / 345$ & $10^{-8} 10^{-9} 10^{-10}$ & $3-1-0$ & 1.28 & $0.29 / 3.48$ \\
\hline Sum of $A+B+C$ & & & 131.4 & & & & 11.46 & \\
\hline MPN of $(A+B+C)$ & $10^{-10} 10^{-11} 10^{-12}$ & $4-4-0$ & 388.7 & $161 / 1035$ & $10^{-9} 10^{-10} 10^{-11}$ & $3-3-0$ & 20.6 & $8.4 / 46.8$ \\
\hline D. The other Fumicutes & $10^{-10} 10^{-11} 10^{-12}$ & $0-1-0$ & 41.4 & $23.0 / 30$ & $10^{-10} 10^{-11} 10^{-12}$ & $1-1-0$ & 48.0 & $12.0 / 180$ \\
\hline E. Actinobacteria & $10^{-8} 10^{-9} 10^{-10}$ & $0-1-0$ & 0.414 & $0.23 / 2.3$ & $10^{-10} 10^{-11} 10^{-12}$ & $0-1-0$ & 21.0 & $12.0 / 120$ \\
\hline F. $\alpha$-proteobacteria & $10^{-10} 10^{-11} 10^{-12}$ & $1-1-0$ & 92.0 & $23.0 / 345$ & - & - & - & \\
\hline G. $\beta$-proteobacteria & $10^{-10} 10^{-11} 10^{-12}$ & $0-2-0$ & 85.1 & 23.0/299 & $10^{-6} 10^{-7} 10^{-8}$ & $0-1-0$ & 0.002 & $0.001 / 0.012$ \\
\hline H. $\gamma$-proteobacteria & $10^{-10} 10^{-11} 10^{-12}$ & $1-1-1$ & 140.3 & $46.0 / 414$ & $10^{-10} 10^{-11} 10^{-12}$ & $1-1-1$ & 73.2 & $24.0 / 216$ \\
\hline I. $\delta$-proteobacteria & $10^{-10} 10^{-11} 10^{-12}$ & $0-0-1$ & 41.4 & $23.0 / 230$ & $10^{-11} 10^{-12} 10^{-13}$ & $2-1-0$ & 840 & $240 / 2520$ \\
\hline $\begin{array}{l}\text { J. The other gram } \\
\text { negative }\end{array}$ & $10^{-6} 10^{-7} 10^{-8}$ & $0-1-0$ & 0.0041 & $0.002 / 0.02$ & $10^{-11} 10^{-12} 10^{-13}$ & $1-1-0$ & 480 & $120 / 1800$ \\
\hline
\end{tabular}

Bacillus benzovorans (Group A, 12 MERFLPs), B.spharicus and B.licheniformis (Group B, 9 MERFLPs), the other Bacillus spp. (Group C, 14 MERFLPs), the other Firmicutes (Group D, 11 MERFLPs), Actinobacteria (Group E, 2 MERFLPs), $\alpha$-proteobacteria (Group F, 3 MERFLPs), $\beta$-proteobacteria (Group G, 4 MERFLPs), $\gamma$-proteobacteria (Group H, 10 MERFLPs), $\delta$-proteobacteria (Group I, 13 MERFLPs), and the other gram negative bacterial group (Group I, 5 MERFLPs) (Table 1).

In the major MERFL, ratio of the MERFLs having 100\% similarity to the corresponding theoretical MERFLs (62.9\%; Table 3) was lower than that of the former study (90.5\%) [1], and the ratio in the 2nd major MERFLs (13.5\%; Table 3) having 100\% similarity to the corresponding theoretical MERFLs was also lower than that of the former study (50.0\%) [1]. This might be caused from a difference of used incubation media as the following; NB medium used in this study was not a selective medium, more diverse microorganisms were proliferated in the each MPN vials than that used in the former study, which made it more difficult to select the MERFLP digested from the homogeneous $16 \mathrm{~S}$ rDNA among the mixed MERFL.

\subsection{Enumeration of Each Bacterial Groups by MPN}

Composting is a biological aerobic decomposition process consisted from different phases; initial phase by the mesophilic microorganisms leading to rapid increase in temperature; the next thermophilic phase when activity and growth of non-thermo-tolerant microorganisms was inhibited and proliferated thermophilic microorganisms took over the degradation process; the final cooling and maturing phase when a new mesophilic microorganismsbecome numerically dominant [3].

The numbers of $B$. benzovorans (Group A) were estimated to be $39.1 \times 10^{8}$ MPN g $^{-1}$ dry matter after thermophilic phase, and decreased to $9.96 \times 10^{8} \mathrm{MPN} \mathrm{g}^{-1}$ after maturing (Table 2). The numbers of B. spharicus and B. licheniformis (Group B) were estimated to be the same level in the both phases, $0.322 \times 10^{8} \mathrm{MPN} \mathrm{g}^{-1}$ and 0.22 $\times 10^{8} \mathrm{MPN} \mathrm{g}^{-1}$, respectively (Table 2). The numbers of the other Bacillus spp. (Group C) decreased form $92.0 \times$ $10^{8} \mathrm{MPN} \mathrm{g}^{-1}$ to $1.28 \times 10^{8} \mathrm{MPN} \mathrm{g}^{-1}$ after maturing (Table 2). Therefore a total number of Bacillus spp. (A + B + C), which was suggested to be a dominant microorganism in thermophilic process [3] [6] [7] [10], decreased to 1/10 after maturing phase (Figure 1). The numbers of the other Firmicutes (Group D) [8], which was sug gested to be a dominant microorganism in the both process, were the same level, $41.4 \times 10^{8} \mathrm{MPN} \mathrm{g}^{-1}$ and $48.0 \times 10^{8}$ MPN g$^{-1}$, respectively (Table 2). The numbers of Actinobacteria (Group E), which was suggested to be a dominant microorganism in maturing process [3] [5] [11], increased from $0.414 \times 10^{8} \mathrm{MPN} \mathrm{g}^{-1}$ to $21.6 \times 10^{8}$ 
MPN after maturing (50 times) (Table 2 and Figure 1). The numbers of $\alpha$-proteobacteria (Group F) decreased from $92.0 \times 10^{8} \mathrm{MPN} \mathrm{g}^{-1}$ to undetectable level after maturing (Table 2). The numbers of $\beta$-proteobacteria (Group G) decreased from $85.1 \times 10^{8} \mathrm{MPN} \mathrm{g}^{-1}$ to $0.002 \times 10^{8} \mathrm{MPN} \mathrm{g}^{-1}$ after maturing (Table 2). Therefore a total number of $\alpha$ and $\beta$-proteobacteria, which included denitrifying bacteria [10], decreased to1/10 $0^{5}$ after maturing phase (Figure 1). The numbers of $\gamma$-proteobacteria (Group H), which was suggested to be a dominant microorganism in the both phase [11], decreased from $140 \times 10^{8} \mathrm{MPN} \mathrm{g}^{-1}$ to $73.2 \times 10^{8} \mathrm{MPN} \mathrm{g}^{-1}$ after maturing (Table 2). The numbers of $\delta$-proteobacteria (Group I) increased from $41.4 \times 10^{8} \mathrm{MPN} \mathrm{g}^{-1}$ to $840 \times 10^{8} \mathrm{MPN} \mathrm{g}^{-1}$ after maturing (Table 2 and Figure 1). The numbers of the other gram negative bacteria (Group J), which was suggested to be a dominant microorganism in maturing process [7] [8], increased from $0.0041 \times 10^{8} \mathrm{MPN} \mathrm{g}^{-1}$ to $480 \times 10^{8} \mathrm{MPN} \mathrm{g}^{-1}$ after maturing $\left(10^{5}\right.$ times) (Table 2 and Figure 1$)$.

An inappropriate MPN score (1-3-0) was observed in B. benzovorans (Group A after maturing) (Table 2), where confidence limit could not be calculated. The inappropriate MPN score was improved by combining few groups, A + B + C (Table 2). The sum of the bacterial numbers using the larger groups, $7.89 \times 10^{10} \mathrm{MPN} \mathrm{g}^{-1}$ after thermophilic phase and $14.83 \times 10^{10} \mathrm{MPN} \mathrm{g}^{-1}$ after maturing, were higher than those using each original groups, $5.32 \times 10^{10} \mathrm{MPN} \mathrm{g}^{-1}$ after thermophilic phase and $14.74 \times 10^{10} \mathrm{MPN} \mathrm{g}^{-1}$ after maturing (Table 2).

Most of Bacillus spp. (A + B + C; 33 MERFLs) were appeared as the major MERFL (94.3\%) (Table 3). They might be amplified preferentially to the other bacterial groups in the used PCR condition due to the PCR bias as described previously. A ratio of gram negative bacteria ( $\mathrm{F}+\mathrm{G}+\mathrm{H}+\mathrm{I}+\mathrm{J} ; 20$ MERFLs) appeared as the major MERFL (57.1\%) was higher than that appeared as the 2nd and 3rd major MERFL (42.9\%) (Table 3). Whereas a ratio of the other gram positive bacteria (D + E; 2 MERFLs) appeared as the major MERFL (18.2\%) was lower than that appeared as the 2nd and 3rd major MERFL (81.8\%) (Table 3). The results suggested that the amplify-

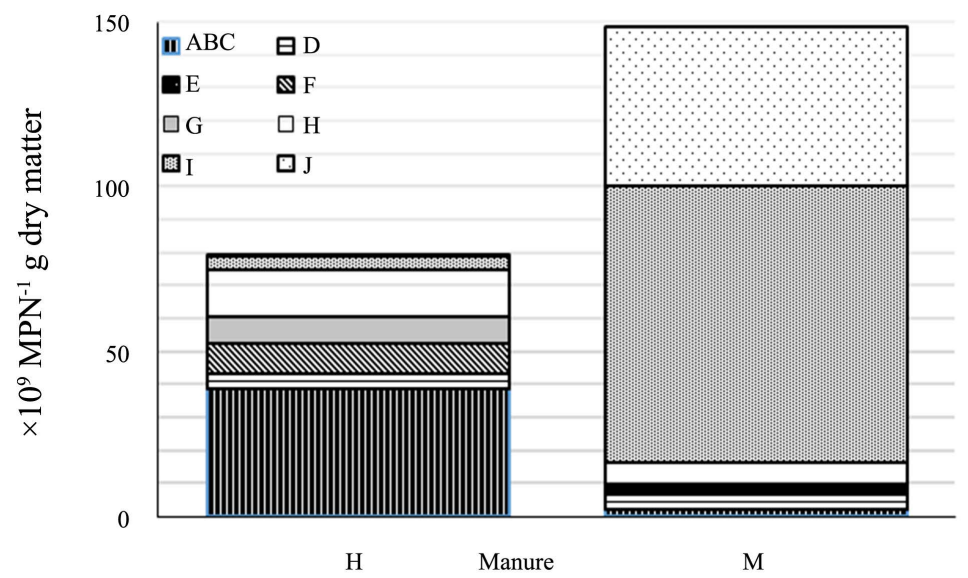

Figure 1. Numbers of bacterial groups estimated by MPN and MERFLP in manure after thermophilic phase $(\mathrm{H})$, and that in maturing phase $(\mathrm{M})$. Number of Bacillus spp. (Group ABC; IIII), the other Firmicutes (Group D; 厈), Actinobacteria (Group E; 1 ), $\alpha$-proteobacteria (Group F; $\beta$-proteobacteria (Group G; $\square$ ), $\gamma$-proteobacteria (Group H; $\square$ ), $\delta$-proteobacteria (Group I; VIII) and the other gram negative bacterial group (Group J; if) were presented.

Table 3. Affiliated bacterial groups of the major, the $2^{\text {nd }}$ major, and $3^{\text {rd }}$ major MERFL and their relation to the results of similarity search.

\begin{tabular}{cccccc}
\hline & \multicolumn{3}{c}{ Bacterial groups } & Ratio of the vails \\
& $\begin{array}{c}\text { Bacillus spp. } \\
\text { (A + B + C) }\end{array}$ & $\begin{array}{c}\text { Gram positive bacteria } \\
\text { (D + E) }\end{array}$ & $\begin{array}{c}\text { Gram negative bacteria } \\
\text { (F + G + H + I + J) }\end{array}$ & $\begin{array}{c}\text { Unidentified } \\
\text { with 100\% similarity }\end{array}$ \\
\hline The major MERFL (54 vials) & 33 & 2 & 20 & 0 & $62.90 \%$ \\
The 2nd major MERFL (52 vials) & 2 & 8 & 14 & 28 & $13.50 \%$ \\
The 3rd major MERFL (4 vials) & 0 & 1 & 1 & 2 & $25.00 \%$
\end{tabular}


cation rate of this group $(\mathrm{D}+\mathrm{E})$ was lower than the Bacillus spp. $(\mathrm{A}+\mathrm{B}+\mathrm{C})$ and gram negative bacteria $(\mathrm{F}+\mathrm{G}$ $+\mathrm{H}+\mathrm{I})$ and their number might be underestimated because of the PCR bias as suggested in the former paper [1].

\section{Conclusions}

In order to estimate microbial number in agricultural soil and manure by PCR using directly extracted DNA, ittook a lot of time and task to remove completely PCR inhibiting substances, such as humic substance contained in the sample [23]-[25]. If the inhibiting substance were remained in a small amount, the amplification rate might drop and sometimes resulted in false-negative result, which caused poor experimental reproducibility [25]. By using this method, false-negative results could be removed as the following reasons: 1) concentration of the inhibiting substance decreased and that of DNA increased because microbial DNA was extracted after proliferation in the growth medium; 2) concentration of the inhibiting substance was diluted and minimized especially in higher decimal dilution vials of MPN, where the numerically more dominant microorganisms have been detected.

When microbial numbers of each groups were estimated by DGGE [26] or clone-library sequencing using directly extracted DNA, PCR bias always disturbed to provide the exact information by changing a ratio of the amplified DNAs from that of the original genomes [27] [28]. As each microbial numbers were estimated by MPN not by an amount of the amplified DNA in this method, PCR bias did not effect on number and composition of numerically dominant microorganisms but their effect was limited in numerically minor microorganisms as the followings: 1) in the highest dilution vail, PCR bias was completely removed because the microbial DNA was originated from a single cell of the numerically most dominant microorganism; 2) in the higher dilution vial, numerically less dominant microorganism can be detected and enumerated, if its amplification rate were higher than that of the most dominant microorganism; 3) in the lower dilution vial, if 16S rDNA of numerically minor microorganism were preferentially amplified to that of numerically dominant microorganism, numerically minor microorganisms can be detected and enumerated.

By this method, bacterial groups concerned with maturing process of manure production were roughly estimated. Although a number of Actinobacteria (E) was high after thermophilic phase, they were only detected in the two higher dilution vials $\left(\mathrm{T} 10^{-9} 1 \mathrm{H}, \mathrm{M} 10^{-11} 2 \mathrm{M}\right.$, Table 1$)$. Actinobacteria was also detected only in two vials in the former study [1]. As the recent research indicated that 16S rDNAs of some Actinobacteria and Firmicutes were not amplified by the used PCR condition, a numbers of Actinobacteria (E) in this study might be underestimated. A new PCR condition including newly designed PCR primers for these bacteria will be presented in the following manuscript. Twenty times increase of a number of $\delta$-proteobacteria after maturing phase could not be explained in normal manure composing process, which was caused from proliferation of various sulfate and sulfite reducing bacteria. The result might be caused from an addition of ammonium sulfate at the starting point in order to adjust carbon nitrogen ratio. As Eukaryote, such as Basidiomycota and Ascomycota, was also reported to contribute to a progress of maturing phase, the method to identify and quantify Eukaryote based on this method will be presented in the following manuscript.

Sum of the bacterial numbers estimated by this method, $7.89 \times 10^{10} \mathrm{MPN} \mathrm{g}^{-1}$ dry weight after thermophilic phase and $14.83 \times 10^{10} \mathrm{MPN} \mathrm{g}^{-1}$ dry weight after maturing, were higher than those estimated by culture dependent methods [2] [3]. For prokaryote, their activity was always connected to proliferation. As microorganisms enumerated in this method were restricted to those proliferated in nutrient broth, which eliminated microorganism losing proliferation ability, the method presented here might be effective and useful for the purpose to monitor bacteria actively proliferated in culture medium.

As the method was a new method, which was different from the other known analysis methods for microbial group such as denaturing gradient gel electrophoresis (DGGE) [29] or terminal restriction fragment length polymorphism (t-RFLP) [30]. Compared to the next-generation method such as pyro-sequencing, by which relative abundance of dominant microorganism was determined after affiliations of all the microorganisms, our method provided information of the most dominant microorganisms preferentially to the minor one more simply and rapidly. As reliable affiliations of all the bacteria might be difficult by our method, our method might not be suitable for pure research purpose, but suitable as inspection method due to its lower running cost and simplicity. A difference of the results obtained by this culture-based technique and that by the unculture-based technique will be presented in the following manuscripts, and the availability as evaluation method for the other microbial 
groups, such as multi-drug resistant bacteria, bacteria causing food poisoning, and bacteria having special functions, a precision of the affiliation, and validation of enumeration of each microbial group will be described in the following manuscripts.

\section{Acknowledgements}

The most of this work had been achieved in Research Team for Biomass Recycling System, National Agricultural Research Center for Kyushu-Okinawa Region. The author thanks Prof. H. Tamura, and Dr. A. Hosoda, Meijyo University, Dr. H. Yosikawa, the former Prof. of Fukuoka Institute of Technology, for their suggestions and encouragements during this work.

\section{References}

[1] Watanabe, K., Horinishi, N. and Matumoto, K. (2015) Antibiotic-Resistant Bacterial Group in Field Soil Evaluated by a Newly Developed Method Based on Restriction Fragment Length Polymorphism Analysis. Advances in Microbiology, 5, 807-816. http://dx.doi.org/10.4236/aim.2015.512085

[2] Shyamala, D.C. and Belagali, S.L. (2014) Seasonal Variation of Microbial Populations during Composting Processes of Municipal Solid Wastes. International Journal of Innovative Research in Science, Engineering and Technology, 3, 14126-14136.

[3] Albrecht, R., Perissol, C., Ruaudel, F., Petit, J.L. and Terrom, G (2010) Functional Changes in Culturable Microbial Communities during a Co-Composting Process: Carbon Source Utilization and Co-Metabolism. Waste Management, 30, 764-770. http://dx.doi.org/10.1016/j.wasman.2009.12.008

[4] Fels, L.E., Ouaqoudi, F-Z.E., Barje, F., Hafidi, M. and Ouhdouch, Y. (2014) Two Culture Approaches Used to Determine the Co-Composting Stages by Assess of the Total Microflora Changes during Sewage Sludge and Date Palm Waste Co-Composting. Journal of Environmental Health Science \& Engineering, 12,132-136. http://dx.doi.org/10.1186/s40201-014-0132-4

[5] Rebollido, R., Martinez, J., Agullera, Y., Melchor, K., Koerner, I. and Stegmann, R. (2008) Microbial Populations during Composting Process of Organic Fraction of Municipal Solid Waste. Applied Ecology and Environmental Research, 6, 61-67. http://www.ecology.uni-corvinus.hu http://dx.doi.org/10.15666/aeer/0603_061067

[6] Schloss, P.D., Hay, A.G., Wilson, D.B. and Walker, L.P. (2003) Tracking Temporal Changes of Bacterial Community Fingerprints during the Initial Stages of Composting. FEMS Microbiology Ecology, 46, 1-9. http://dx.doi.org/10.1016/S0168-6496(03)00153-3

[7] Sasaki, H., Nonaka, J., Otawa, K., Kitazume, O., Asano, R., Sasaki, T. and Nakai, Y. (2009) Analysis of the Structure of the Bacterial Community in the Livestock Manure-Based Composting Process. Asian-Australasian. Journal of Animal Science, 22, 113-118.

[8] Yamamoto, N., Otawa, K. and Nakai, Y. (2009) Bacterial Communities Developing during Composting Processes in Animal Manure Treatment Facilities, Asian-Australasian. Journal of Animal Science, 22, 900-905.

[9] Guo, Y., Zhang, J., Yan, Y., Wu, J., Zhu, N. and Deng, C. (2015) Molecular Phylogenetic Diversity and Spatial Distribution of Bacterial Communities in Cooling Stage during Swine Manure Composting. Asian-Australasian. Journal of Animal Science, 28, 888-895.

[10] Cahyani, V.R., Matsuya, K., Asakawa, S. and Kimura, M. (2003) Succession and Phylogenetic Composition of Bacterial Communities Responsible for the Composting Process of Rice Straw Estimated by PCR-DGGE Analysis. Soil Science and Plant Nutrition, 49, 619-630. http://dx.doi.org/10.1080/00380768.2003.10410052

[11] Danon, M., Franke-Whittle, I.H., Insam, H., Chen, Y. and Hadar, Y. (2008) Molecular Analysis of Bacterial Community Succession during Prolonged Compost Curing. FEMS Microbiology Ecology, 65, 133-144. http://dx.doi.org/10.1111/j.1574-6941.2008.00506.X

[12] Partanen, P., Hultman, J., Paulin, L., Auvinen, P. and Romantschuk, M. (2010) Bacterial Diversity at Different Stages of the Composting Process. BMC Microbiology, 10, 94-104. http://dx.doi.org/10.1186/1471-2180-10-94

[13] Song, C., Li, M., Jia, X., Wei, Z., Zhao, Y., Xi, B., Zhu, C. and Liu, D. (2014) Comparison of Bacterial Community Structure and Dynamics during the Thermophilic Composting of Different Types of Solid Wastes: Anaerobic Digestion Residue, Pig Manure and Chicken Manure. Microbial Biotechnology, 7, 424-433. http://dx.doi.org/10.1111/1751-7915.12131

[14] Neher, D.A., Weicht, T.R., Bates, S.T., Leff, J.W. and Fierer, N. (2013) Changes in Bacterial and Fungal Communities across Compost Recipes, Preparation Methods, and Composting Times. PLoS ONE, 8, e79512.

http://dx.doi.org/10.1371/journal.pone.0079512 
[15] Watanabe, K., Okuda, M. and Koga, N. (2008) A Newly Developed System Based on Multiple Enzyme Restriction Fragment Length Polymorphism-An Application to Proteolytic Bacterial Flora Analysis. Soil Science and Plant Nutrition, 54, 204-215. http://dx.doi.org/10.1111/j.1747-0765.2007.00230.x

[16] Watanabe, K. and Koga, N. (2009) Use of a Microchip Electrophoresis System for Estimation of Bacterial Phylogeny and Analysis of $\mathrm{NO}_{3}{ }^{-}$Reducing Bacterial Flora in Field Soils. Bioscience Biotechnology and Biochemistry, 73, 479488. http://dx.doi.org/10.1271/bbb.70712

[17] Schewieger, F. and Tebbe, C.C. (1998) A New Approach To Utilize PCR-Single-Strand-Conformation Polymorphism for 16S rRNA Gene-Based Microbial Community Analysis. Applied and Environmental Microbiology, 64, 4870-4876.

[18] Weidner, S., Arnold, W. and Puhler, A. (1996) Diversity of Uncultured Microorganisms Associated with the Seagrass Halophila stipulacea Estimated by Restriction Fragment Length Polymorphism Analysis of PCR-Amplified 16S rRNA Genes. Applied and Environmental Microbiology, 62, 766-771.

[19] Watanabe, K. (2008) Application of Multiple Enzyme Restriction Fragment Length Polymorphism Analysis and Microchip Electrophoresis for Estimation of Antibiotic-Tolerant Bacterial Group. Journal of Pesticide Science, 33, 249260. http://dx.doi.org/10.1584/jpestics.G08-04

[20] Watanabe, K. and Okuda, M. (2003) Method and System for Searching for Relationships between Base Sequences in Genes. Japanese Patent No. 3431135, US Patent No. 7006924.

[21] Nei, M. and Li, W.H. (1979) Mathematical Model for Studying Genetic Variation in Terms of Restriction Endonucleases. Proceedings of the National Academy of Sciences of the United States of America, 76, 5269-5273. http://dx.doi.org/10.1073/pnas.76.10.5269

[22] Haas, C.N. (1989) Estimation of Microbial Densities from Dilution Count Experiments. Applied and Environmental Microbiology, 55, 1934-1942.

[23] Tebbe, C.C. and Vahjen, W. (1993) Interference of Humic Acids and DNA Extracted Directly from Soil in Detection and Transformation of Recombinant DNA from Bacteria and a Yeast. Applied and Environmental Microbiology, 59, 2657-2665.

[24] Tsai, Y.L. and Olson, B.H. (1991) Rapid Method for Direct Extraction of DNA from Soil and Sediments. Applied and Environmental Microbiology, 57, 1070-1074.

[25] Watanabe, K. (2009) Detection of Protease Gene in the Field Soil Applied with Liquid Livestock Feces and Speculation of Their Function and Origin. Soil Science and Plant Nutrition, 55, 42-52. http://dx.doi.org/10.1111/j.1747-0765.2008.00323.x

[26] Neilson, J.W., Jordan, F.L. and Maier, R.M. (2013) Analysis of Artifacts Suggests DGGE Should Not Be Used For Quantitative Diversity Analysis. Journal of Microbiological Method, 92, 256-263. http://dx.doi.org/10.1016/j.mimet.2012.12.021

[27] Direito, S.O.L., Zaura, E., Little, M., Ehrenfreund, P. and Röling, W.F.M. (2014) Systematic Evaluation of Bias in Microbial Community Profiles Induced by Whole Genome Amplification. Environmental Microbiology, 16, 643-657. http://dx.doi.org/10.1111/1462-2920.12365

[28] Ishii, K. and Fukui, M. (2001) Optimization of Annealing Temperature to Reduce Bias Caused by a Primer Mismatch in Multitemplate PCR. Applied and Environmental Microbiology, 67, 3753-3755. http://dx.doi.org/10.1128/AEM.67.8.3753-3755.2001

[29] Muyzer, G., Waal, E.C.D. and Uitterlinden, A.G. (1993) Profiling of Complex Microbial Populations by Denaturing Gradient Gel Electrophoresis Analysis of Polymerase Chain Reaction-Amplified Genes Coding for 16S rRNA. Applied and Environmental Microbiology, 59, 695-700.

[30] Marsh, T.L., Saxman, P.L., Cole, J. and Tiedje, J.M. (2000) Terminal Restriction Fragment Length Polymorphism Analysis Program, a Web-Based Research Tool for Microbial Community Analysis. Applied and Environmental Microbiology, 66, 3616-3620. http://dx.doi.org/10.1128/AEM.66.8.3616-3620.2000 